\title{
INACCURACIES OF INDUSTRIAL ROBOT POSITIONING AND METHODS OF THEIR CORRECTION
}

\author{
Milan Marônek, Jozef Bárta, Jozef Ertel
}

Original scientific papers

The application of production lines without the use of robots in heavy, monotonous, unhealthy or high-precision works is not just ineffective and inhumane but also economically unprofitable. The use of robotics in manufacturing processes is therefore necessary to ensure high productivity of products having satisfactory quality and guaranteed repeatability of production. The article points out inaccuracies in positioning the robotic arm tool depending on the robot axes rotation, welding speed and predefined trajectory shape. Fanuc M-710iC/50 robot showed biggest inaccuracies in movement speed of $50 \mathrm{~mm} / \mathrm{s}$.

Keywords: accuracy; correction; production; robot

Netočnosti pozicioniranja industrijskih robota i načini njihovog ispravljanja

Izvorni znanstveni članak Primjena proizvodnih linija bez uporabe robota u teškim, monotonim, nezdravim ili visoko preciznim radovima ne samo da je neučinkovita i nehumana već je i ekonomski neprofitabilna. Primjena robotike u proizvodnim procesima stoga je potrebna kako bi se osigurala visoka produktivnost proizvoda zadovoljavajuće kvalitete i garantiranog ponavljanja u proizvodnji. U radu se ukazuje na netočnosti u pozicioniranju ruke robota ovisno o rotaciji osovine robota, brzini zavarivanja i predviđenoj putanji. Robot Fanuc M-710iC/50 pokazao je najveće netočnosti kod kretanja brzinom od $50 \mathrm{~mm} / \mathrm{s}$.

Ključne riječi: proizvodnja; putanja; robot; točnost

\section{Introduction}

When applying industrial robots even in very accurate industrial applications, the question of real and repeatable accuracy of robotic arms becomes more actual (Fig. 1). The accuracy of robot depends on its design, construction rigidity and range. The basic parameters of selected industrial robots are in Table 1. Movement accuracy is also important in laser beam welding requiring very precise robotic arm movement with regard to narrow weld width and demands on beam focusing accuracy [1-9].

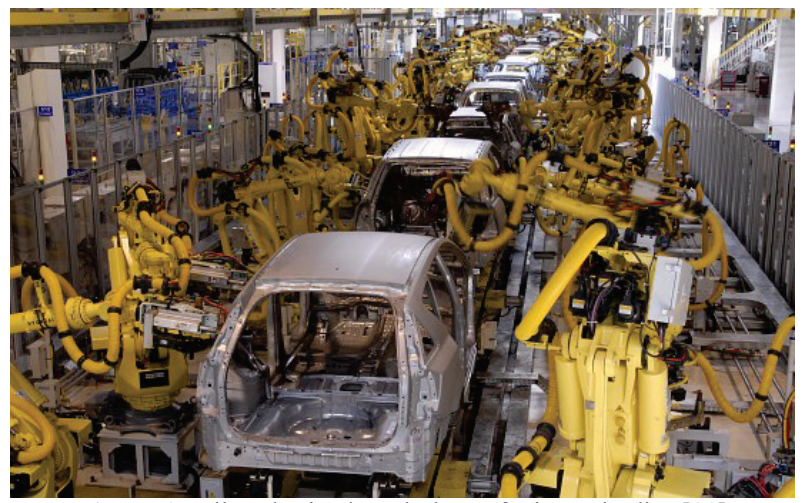

Figure 1 Fully robotized workplace of Kia car bodies [11]

Table 1Properties comparison of selected types of Fanuc industrial robots [2]

\begin{tabular}{|c|c|c|c|c|}
\hline Robot & $\begin{array}{c}\mathrm{M}-10 \\
\mathrm{iA} / 10 \mathrm{M}\end{array}$ & $\begin{array}{c}\mathrm{M}-710 \\
\mathrm{iC} / 50\end{array}$ & $\begin{array}{c}\mathrm{M}-900 \\
\mathrm{iB} / 700\end{array}$ & $\begin{array}{c}\mathrm{M}-2000 \\
\mathrm{iA} / 1200\end{array}$ \\
\hline Repeatability (mm) & 0,08 & 0,07 & 0,3 & 0,3 \\
\hline Range (mm) & 2844 & 4100 & 5664 & 7468 \\
\hline Maximal load (kg) & 10 & 50 & 700 & 1200 \\
\hline
\end{tabular}

The FANUC industrial robot commonly applied in different industrial application was chosen for experiment. We suppose that serially produced robots of different manufacturers will behave similarly.

More authors are dealing with the robotic applications as well as offline programming but these applications have to be careful in comparing the theory to real manufacture, where errors may occur $[14,15,16]$. Customers are mostly relying on information provided by manufacturers who declare that the precision of positioning to specified point is very accurate. On the other hand relevant references regarding the accuracy of trajectory itself are missing. These facts were the main reasons why this research was carried out [4].

\section{Equipment \& Material}

Industrial robot FANUC $\mathrm{M}-710 \mathrm{iC} / 50$ is a six-axis modular construction. This device belongs at a moment to the most often used, thanks to its excellent ratio between base size and range $(4100 \mathrm{~mm})$ and universal usage.
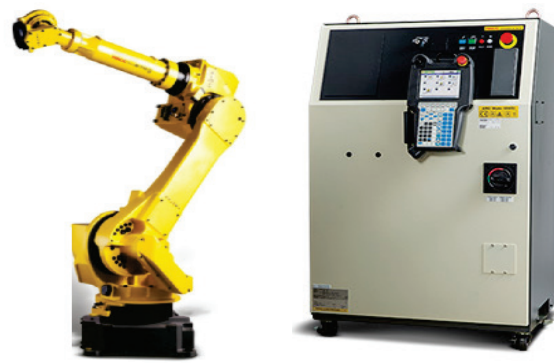

Figure 2 Industrial robot Fanuc M-710iC/50 (left) and ControllerBCabinet withTeach pedant (right)

The Fanuc robotic arm (Fig. 2) is suitable for applications which require constant force (polishing, deburring) and other production applications such as arc, spot, laser and other welding methods, adhesive joining, material manipulation and presswork finishing. The arm 
is terminated with a compact wrist allowing action in narrow spaces (car body interior), or during arc welding of big weldments. Even with maximum load capacity of $50 \mathrm{~kg}$ at the last axis, the arm is able to avoid collision in low-lying areas or small openings.

The direct connection of motors with reductors provides simpler construction of mechanical unit thus lowering the risk of failure, compact and reliable solution or high accuracy and minimal clearance in gearing. The robotic arm is controlled by compatible system Fanuc R$30 \mathrm{iB}$ installed in control B-Cabinet unit (Fig. 2) [2].

Each workspace with robots should be limited in regard to the robot range and accuracy to ensure reasonable accuracy [12]. To improve the accuracy and project the workspace, offline programming software is often supplied with robots. Current tendencies are oriented to implement virtual reality to robot control systems [13].

\section{Methods}

Cold rolled sheets of DC01 steel with dimensions of $100 \times 100 \times 1,5 \mathrm{~mm}$ were used for experiment. Penetration welds on samples were carried out by TRUMPF TruDisk 4002 laser along to predefined trajectory [10].

The laser beam of $1,03 \mu \mathrm{m}$ wave length was conducted to the laser head Trumpf D70 by optical cable with diameter of $200 \mu \mathrm{m}$. The diameter of focused laser beam spot was $200 \mu \mathrm{m}$. The laser head was positioned by six axis robotic arm Fanuc M-710iC/50 at different speed $25,50,100$ and $250 \mathrm{~mm} / \mathrm{s}$ respectively. In order to create a foot mark on the material surface, no protective gas was used. The measurement of trajectory deviation was carried out by digital microscope DinoXLite at $50 \times$ magnification.

The laser head angular trajectory comprised three nodal points defining two linear movements. In the field of welding, where these robots are often applied, it is important to provide constant movement speed along whole trajectory. If movement speed is not constant, the correction of welding parameters should be undertaken in the sections of trajectory having different movement speed. Therefore CNT (continuous) mode was applied, despite the fact that robot can be led along the trajectory with higher accuracy by "FINE" movement command.

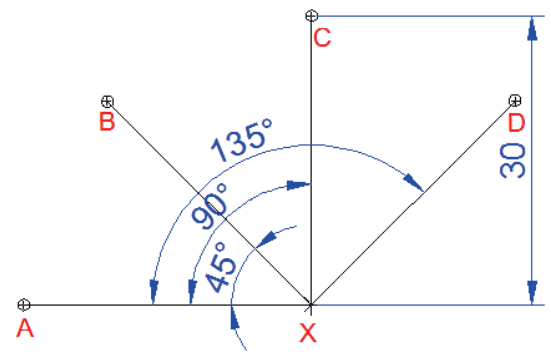

Figure 3 Predefined trajectory of laser head (top) and deviation measurement example (bottom)

The nodal points created virtual apex angles $\mathrm{AXB}=$ $45^{\circ}, \mathrm{AXC}=90^{\circ}$ and $\mathrm{AXD}=135^{\circ}$ (Fig. 3) and were marked on sheet plate surface by Sauer Lasertec equipment. In the ideal case, the laser beam spot should pass through apex $\mathrm{X}$ point being part of predefined trajectory. Actually, the decline in $X$ and $Y$ axes creating deviations $\Delta X$ and $\Delta Y$ were observed. In order to perform precise deviation measurements by DinoCapture software, the apex points were marked as a star mark with $2 \mathrm{~mm}$ in diameter. The deviation from ideal trajectory was evaluated as the shortest distance from star centre to the centre of penetration weld width (Fig. 4).

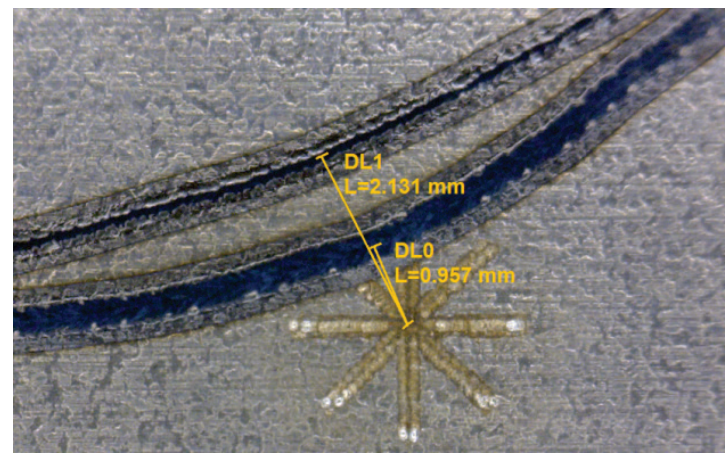

Figure 4 Predefined trajectory of laser head (top) and deviation measurement example (bottom)

Movement along every angular trajectory was performed at speed 25, 50, 100 and $250 \mathrm{~mm} / \mathrm{s}$ respectively. The laser beam power output at speeds 25 and $50 \mathrm{~mm} / \mathrm{s}$ was $80 \mathrm{~W}$ and $100 \mathrm{~W}$ at speeds 100 and 250 $\mathrm{mm} / \mathrm{s}$. For easier visualisation and mutual comparison, the resultant surface traces of laser beam were redrawn in graphic software.

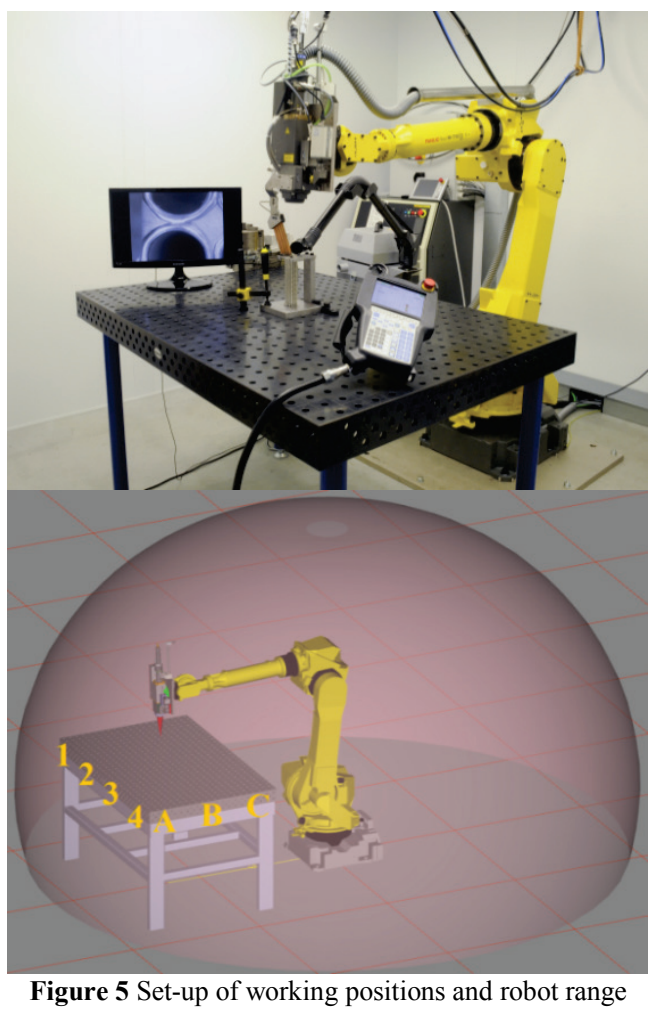

Industrial robot accuracy measurements consisted of four experimental parts. The deviations from predefined trajectory as dependence on axes rotation were examined in the first part. There was an assumption that the distance of laser head from robot base will affect the deviation. The evaluation was carried out for three angular trajectory movements (trajectories AXB, AXC and AXD) at three different positions on work table (A4, B2-3, C1) and all 
welding speeds (Fig. 5). The approximate angular positions of particular axes $\left(J_{1}\right.$ to $\left.J_{6}\right)$ together with distance from robot base are presented in Tab. 2. As the significant deviations in these three positions were observed, mapping of whole table area was consequently performed. Finally the "topographic" deviation map was created for twelve positions on work table at welding speed $50 \mathrm{~mm} / \mathrm{s}$ and AXC trajectory.

Table 2 Laser head distance from the robot base and axe rotation of the robot for selected positions

\begin{tabular}{|c|c|c|c|c|c|c|}
\hline \multirow{2}{*}{$\begin{array}{l}\text { Working } \\
\text { position }\end{array}$} & \multicolumn{6}{|c|}{ Laser head to robot base distance (mm) } \\
\hline & \multicolumn{2}{|r|}{$X$} & \multicolumn{2}{|l|}{$Y$} & \multicolumn{2}{|c|}{$Z$} \\
\hline $\mathrm{A} 4$ & \multicolumn{2}{|c|}{1621,13} & \multicolumn{2}{|c|}{696,92} & \multicolumn{2}{|c|}{373,00} \\
\hline B2-3 & \multicolumn{2}{|c|}{1221,78} & \multicolumn{2}{|c|}{46,13} & \multicolumn{2}{|c|}{372,72} \\
\hline $\mathrm{C} 1$ & \multicolumn{2}{|c|}{831,98} & \multicolumn{2}{|c|}{$-600,96$} & \multicolumn{2}{|c|}{372,69} \\
\hline \multirow{2}{*}{$\begin{array}{l}\text { Working } \\
\text { position }\end{array}$} & \multicolumn{6}{|c|}{ Approximate axe rotation $\left({ }^{\circ}\right)$} \\
\hline & $J_{1}$ & $J_{2}$ & $J_{3}$ & & $J_{5}$ & $J_{6}$ \\
\hline A4 & 26,70 & 23,89 & $-13,62$ & -57 & 30,10 & 145,32 \\
\hline B2-3 & 2,16 & $-13,60$ & $-16,44$ & -1 & 19,60 & 91,57 \\
\hline $\mathrm{C} 1$ & $-46,59$ & $-22,75$ & $-14,01$ & & 50,71 & 20,81 \\
\hline
\end{tabular}

The second part of experiment investigated deviations from predefined trajectory as dependence on welding speed and trajectory shape. The examination was done by making laser beam traces on sheet surface at different angular trajectory shape (AXB, AXC and AXD) in B2-3 position on work table (Fig. 5). We supposed that the deviation values would be related to the speed of laser head as well as the trajectory shape.

The last two parts of experiment studied the possibilities of deviation correction when AXC trajectory in working position B2-3 was performed (Fig. 6). The goal of the third part of experiment was to get closer to the nodal $\mathrm{X}$ point, so insertion of two new nodal points $\mathrm{K}$ and $\mathrm{N}$ together with decreasing the welding speed in this section of trajectory was applied.

The correction by shifting the nodal X point (Fig. 6) and insertion of new nodal points was the subject of the last part of experiment. There was assumption, that due to the robot's control system effort to pass through inserted nodal points, the final deviation will be smaller.

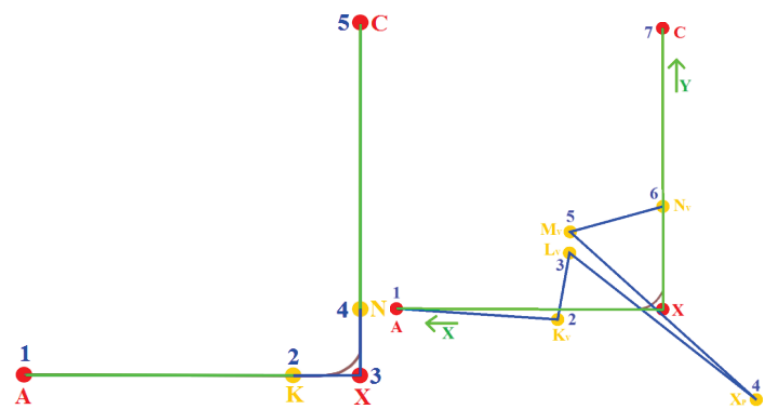

Figure 6 Graphical representation of the predefined trajectories with inserted nodal points $\mathrm{K}$ and $\mathrm{N}$ in front and behind $\mathrm{X}$ point (left) and inserted points $\left(K_{V}, L_{V}, M_{V}, N_{V}\right)$ with $X_{P}$ nodal point shift (right)

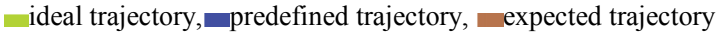

Table 3 Coordinates of inserted points and shifted point $X_{P}$ in relation

\begin{tabular}{|c|c|c|c|c|c|c|}
\hline \multicolumn{1}{c|}{ to point position } \\
\hline Point & $\mathrm{X}$ & $\mathrm{X}_{\mathrm{p}}$ & $\mathrm{K}_{\mathrm{v}}$ & $\mathrm{L}_{\mathrm{v}}$ & $\mathrm{M}_{\mathrm{v}}$ & $\mathrm{N}_{\mathrm{v}}$ \\
\hline$x$ axis direction $(\mathrm{mm})$ & 0 & 3,9 & $-4,4$ & $-3,9$ & $-3,9$ & 0 \\
\hline$y$ axis direction $(\mathrm{mm})$ & 0 & $-3,7$ & $-0,3$ & 2,5 & 3,3 & 4,4 \\
\hline
\end{tabular}

The coordinates of inserted nodal points as well as nodal point $\mathrm{X}_{\mathrm{P}}$ shift are presented in Tab. 3. The sequence of robot's trajectories, following nodal points from 1 to 7 , is illustrated in Fig. 5.

\section{Results}

The results of the first part of experiment proved the assumption that there will be deviations between real and predefined trajectory of laser beam in continuous mode of movement (Tab. 4). It is obvious, that the most precise movements of robotic arm were acquired for axes rotation corresponding to working position B2-3, and the least ones in working positions $\mathrm{A} 4$ and $\mathrm{C} 1$ (Fig. 5). The dependence of average deviation versus welding speed at different working positions is presented in Fig. 6.

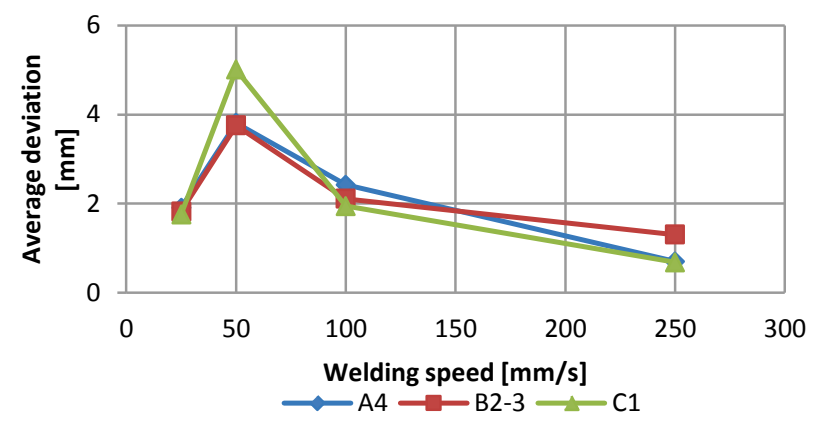

Figure 7Average deviations versus welding speed at particular working positions

Based on particular results shown in Fig. 7, it is possible to conclude that $\mathrm{C} 1$ position had the biggest deviation with welding speed of $50 \mathrm{~mm} / \mathrm{s}$; however it also showed the smallest deviation in welding speed of $250 \mathrm{~mm} / \mathrm{s}$.

The summary of average deviations at different working positions for AXC trajectory and welding speed is presented in Fig. 8. It is recommended to situate welding fixture as close to the working position C3 (Fig. 5) as possible.

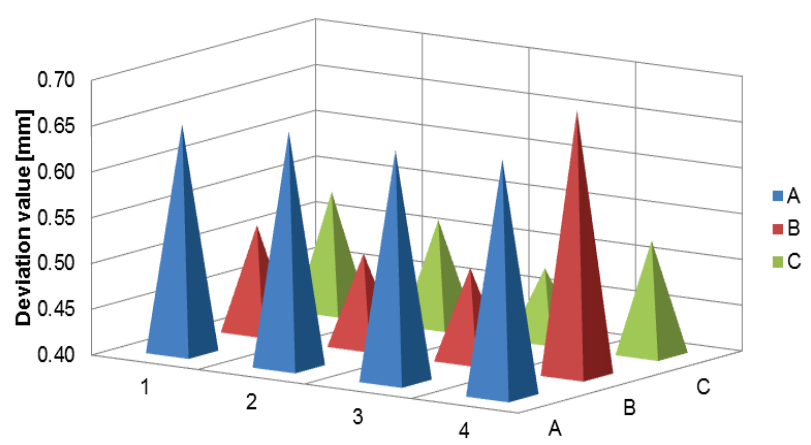

Figure 8 Topographic map of deviations at particular working positions for welding speed of $50 \mathrm{~mm} / \mathrm{s}$

The results of the second part of the experiment proved the assumption that deviation values between real and predefined trajectory depend on welding speed (Tab. 4, Fig. 9) and trajectory shape (Tab. 4, Fig. 10).

Analysis of deviation values as dependence on welding speed showed that deviation values were reverse to the trajectory's apex angle. The lowest deviations were reached at welding speed of $250 \mathrm{~mm} / \mathrm{s}$. 
Table 4 Deviations between real and predefined trajectory for particular welding speed $(\mathrm{mm})$

\begin{tabular}{|c|c|c|c|c|c|}
\hline \multirow{2}{*}{ Sample code } & \multirow{2}{*}{ Shape of real trajectories } & \multicolumn{4}{|c|}{ Deviation value from nodal point $X$ for different welding speed $(\mathrm{mm} / \mathrm{s})$} \\
\hline & & 25 & 50 & 100 & 250 \\
\hline A4_45 & & 2,548 & 5,014 & 3,301 & 0,948 \\
\hline A4_90 & & 2,215 & 6,580 & 2,634 & 0,768 \\
\hline A4_135 & & 0,957 & 2,131 & 1,329 & 0,387 \\
\hline B2-3_45 & & 2,593 & 5,255 & 3,007 & 1,839 \\
\hline B2-3_90 & & 1,954 & 3,962 & 2,290 & 1,344 \\
\hline B2-3_135 & & 0,928 & 2,044 & 1,034 & 0,737 \\
\hline C1_45 & & 2,476 & 6,906 & 2,684 & 0,904 \\
\hline C1_90 & & 1,865 & 5,297 & 1,974 & 0,706 \\
\hline C1_135 & & 0,935 & 2,827 & 1,175 & 0,443 \\
\hline
\end{tabular}

The results of the third part of the experiment demonstrated that correction of deviation between real and predefined trajectory was possible. Insertion of nodal points into the predefined trajectory lowered final deviation, but only to the particular distance of inserted points from the $\mathrm{X}$ nodal point (Fig. 11). The more significant effect on deviation values had welding speed reduction between nodal points $\mathrm{KX}$ and $\mathrm{XN}$.

The results of the last part of the experiment approved expectation that deviation correction is also possible by inserting and shifting the subsidiary four points as well as the $\mathrm{X}$ point. This procedure provided direct pass through $\mathrm{X}$ point with no requirement on 
welding speed change, but on the other hand, it generated new three deviations - one in the $\mathrm{X}$ and two in the $\mathrm{Y}$ axis (Fig. 12). However, the largest one $(2,045 \mathrm{~mm})$ was still lower than the deviation of uncorrected trajectory $(3,962$ $\mathrm{mm})$.

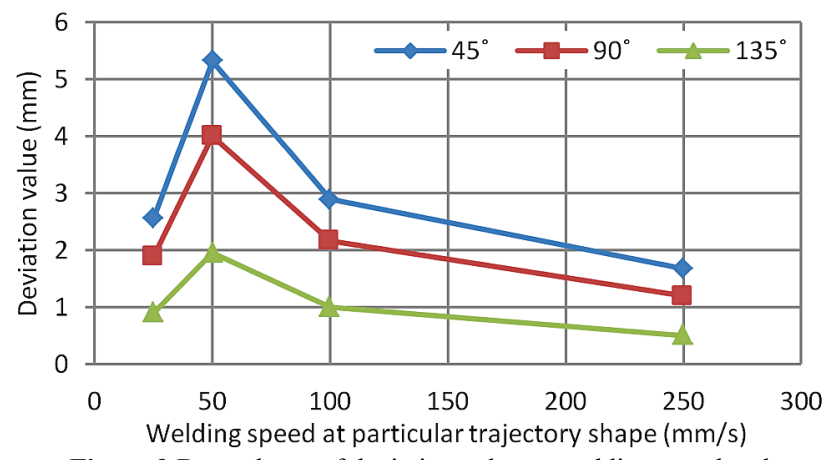

Figure 9 Dependence of deviation value on welding speed and trajectory shape

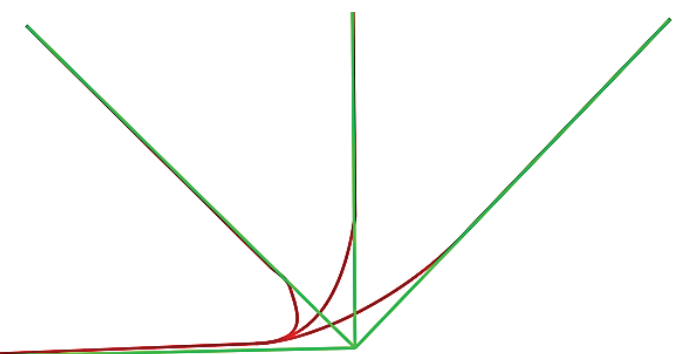

Figure 10 Graphical representation of deviations at different predefined moving trajectories: - predefined moving trajectory, $\square$ real moving trajectory

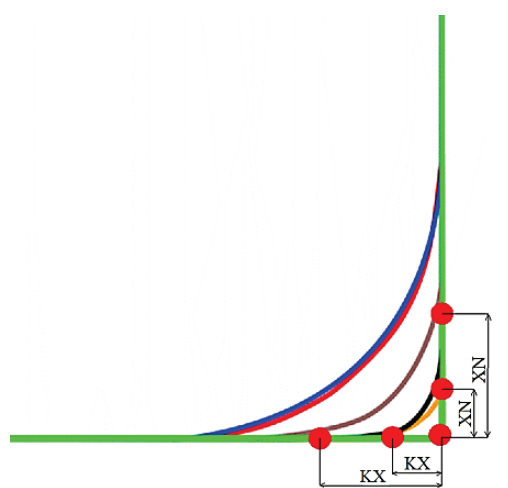

Figure 11The measured deviations from ideal trajectory as dependence on different welding speed $\left(v_{\mathrm{P}}\right)$ and distance of inserted points $\mathrm{K}$ and $\mathrm{N}$ from the centre point X: ideal trajectory, $\square v_{\mathrm{P}}=100 \mathrm{~mm} / \mathrm{s}, \quad v_{\mathrm{P}}=50$ $\mathrm{mm} / \mathrm{s} ; \mathrm{KX}=\mathrm{XN}=5 \mathrm{~mm}, \quad v_{\mathrm{P}}=100 \mathrm{~mm} / \mathrm{s}, \quad v_{\mathrm{P}}=50 \mathrm{~mm} / \mathrm{s}$ for KX=XN $=2 \mathrm{~mm}$, uncorrected trajectory without nodal points $\mathrm{K}, \mathrm{N}$

\section{Conclusion}

The industrial robot positioning system accuracy plays an important part during selection of welding method, material or the robot itself. The experiment proved the influence of laser head distance from robot base, welding speed as well as the trajectory shape on final deviation. The results revealed two possible concepts of deviation correction. The first one based on insertion of additional points into original robot trajectory near to the $\mathrm{X}$ nodal point brought some improvement. However, the second concept utilizing insertion of nodal points outside the original trajectory showed better results. Despite some trajectory irregularities, the total deviation was lower than the deviation obtained by the first concept.

The manufacturers of industrial robots declare the repeatability, but they do not specify the accuracy of movement along predefined trajectory. The results showed that in case of requirement on predefined trajectory accuracy, it is essential to take into account also the position of trajectory within robot's reach as well as the speed of movements. In case of using Fanuc M$710 \mathrm{iC} / 50$ robot for complicated trajectories, one should avoid welding speed of $50 \mathrm{~mm} / \mathrm{s}$ as it showed the biggest deviations.

As it was mentioned before, probably all robot manufacturers will have the same issues regarding movement accuracy. Another solution to increase the accuracy of the robot is the calibration. This procedure is time and money consuming and in case of robot collision it is necessary to repeat it. Therefore, calibrated robots are not so often used in production.

\section{Acknowledgement}

This paper was supported by scientific grant agency of Ministry of education of Slovak republic (project VEGA No. 1/0470/14) and European Union projects "Excellence centre of 5 axes machining, ITMS 26220120013" and "Excellence centre of 5 axes machining - experimental basis for Hi-Tech research, ITMS 26220120045."
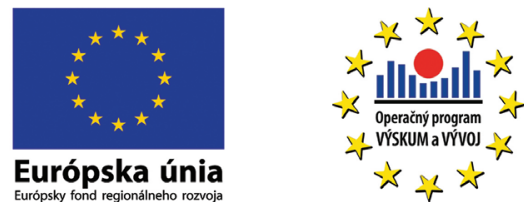

\section{References}

[1] Mooring, W. B.; Roth, S. Z.; Driels, R. M. Fundamentals of manipulator calibration. A Wiley - Interscience Publication, New York, 1991.

[2] Fanuc company. Leaflet of $\mathrm{M}-710 \mathrm{iC} / 50$. 2009. URL: http:/www.fanucrobotics.cz/cs/products/a industrialrobots $/ \mathrm{m}-710$ series $/ \mathrm{m}-710 \mathrm{ic} \% 2050$. (05.10.2013).

[3] Ábel, M.; Viňáš, J.; Antoszewski, B. Analysis of welded joints of drawing quality and high strength steels. // PROTECH-MA 2012 - international scientific conference, 25 27 June 2012, Herl'any - Košice : TU, 2012 pp. 6-10.

[4] Wollnack, J. Precision increase of industrial robots. 2001. URL: http://www.tuhh.de/ft2/wo/Paper/AsiarSymp.pdf. (08.11.2013) 
[5] Kalaš V. Tridsat' rokov svetovej robotiky. // AT\&P journal, The web version (2005), URL: http://www.atpjournal.sk/ buxus/docs/atp-2005-03-76.pdf. (20.11.2013).

[6] Curkovic, P.; Jerbic, B.; Stipancic, T. Coordination of Robots with Overlapping Workspaces Based on Motion Co-evolution. // International Journal of Simulation Modelling. 12, 1(2013), pp. 27-38. DOl: 10.2507/IJSIMM12(1)3.222

[7] Ge, D. Y.; Yao, X. F.; Yao, Q. H.; Jin, H. Robot sensor calibration via neural network and particle swarm optimization enhanced with crossover and mutation. // Tehnicki vjesnik-Technical Gazette. 21, 5(2014), pp. 10251033.

[8] Chatterjee, P.; Mondal, S.; Chakraborty, S. A comparative study of preference dominance-based approaches for selection of industrial robots. // Advances in Production Engineering \& Management. 9, 1(2014), pp. 5-20. DOl: 10.14743/apem2014.1.172

[9] Bozek, P. Robot path optimization for spot welding applications in automotive industry. // Tehnicki vjesnikTechnical Gazette. 20, 5(2014), pp. 913-917.

[10] Data sheet: B3.1. Cold Rolled Steel Sheet for Drawing and Forming EN 10130 DC01 - DC06. URL: https://flatsteel. arcelormittalsa.com/fspcatalogue/DataSheets/UnCoated/We b_datasheet_b3.1.pdf. (02.12.2013).

[11] Hombauer, R. Kia Sportage - how it is made. URL: http://zavolantom.autovia.sk/2010/07/09/ako-sa-vyrabanielen-kia-sportage/. (15.12.2013).

[12] Monková, K.; Hloch S.; Šmerigajová, A. The determination of robot workspace for manufacturing cell definition. // Proceedings of IMC 2011: International multidisciplinary conference/ Baia Mare, Romania, Nyíregyháza, Hungary. Nyíregyháza, 2011, pp. 189-194.

[13] Novak-Marcinčin, J.; Doliak, M.; Hloch, S.; Ergić, T. Application of the Virtual Reality Modelling Language to Computer Aided Robot Control System ROANS. // Strojárstvo, Strojárenství. 52, 2(2010), pp. 227-232.

[14] Kržič, P.; Pušavec, F.; Kopač, J. Kinematic constraints and offline programming in robotic machining applications. // Tehnicki vjesnik-Technical Gazette. 20, 1(2013), pp. 117124.

[15] Božek, P. Robot path optimization for spot welding application in automotive industry. // Tehnicki vjesnikTechnical Gazette. 20, 5(2013), pp. 913-917.

[16] Ivandič, Ž.; Ergić, T.; Kljajin, M. Welding robots kinematic structures evaluation of based on conceptual models using the Potential method. // Tehnicki vjesnik-Technical Gazette. 16, 4(2009), pp. 35-45.

\section{Authors' addresses}

Milan Maronek, Prof. Ing. PhD.

Slovak University of Technology in Bratislava, Faculty of Materials Science and Technology in Trnava Paulínska 16, 91724 Trnava, Slovakia

E-mail: milan.maronek@stuba.sk

\section{Jozef Bárta, Ing. PhD.}

Slovak University of Technology in Bratislava, Faculty of Materials Science and Technology in Trnava

Paulínska 16, 91724 Trnava, Slovakia

E-mail: jozef.barta@stuba.sk

\section{Jozef Ertel, Ing.}

Slovak University of Technology in Bratislava, Faculty of Materials Science and Technology in Trnava

Paulínska 16, 91724 Trnava, Slovakia

E-mail: jozef.ertel@stuba.sk 